\title{
DIVERSIFICATION OF STUDENTS BY SUCCESS PREDICTORS IN INFORMATION SCIENCE ORIENTED SPOC COURSES
}

Michal MRÁZEK* , Univerzita Palackého v Olomouci, Česká republika Jaromír BASLER, Univerzita Palackého v Olomouci, Česká republika

Přijato: 17. 9. 2019 / Akceptováno: 15. 4. 2020

Typ článku: Teoretická studie

DOI: $10.5507 /$ jtie.2020.007

Abstract: The present paper describes the results of a research study performed in the context of implementation of SPOC courses in Basics of programming and Information technology and information science as part of university training of future teachers of technical and informatics subjects. The aim of the research was to determine which groups of students could be identified by success predictors in the SPOC course. The design of the research was based on quantitative data collection and assessment methods. The survey was performed by means of a questionnaire designed by the authors and involving 44 respondents. The data obtained were analysed using multidimensional statistical data, especially the cluster analysis methods. The results suggested that the respondents could be classified by 11 predictors into two distinctive groups.

Key words: teacher training, e-learning, small private online courses, success predictors

\section{DIVERZIFIKACE STUDENTŮ PODLE PREDIKTORŮ ÚSPĚŠNOSTI V INFORMATICKY ZAMĚŘENÝCH SPOC KURZECH}

Abstrakt: Prezentovaný článek popisuje výsledky výzkumu, který byl realizován v rámci implementace SPOC kurzù v predmětech Základy programování, Informační technologie a informatika $v$ univerzitní př́pravě budoucích učitelì techniky a informatiky. Cílem výzkumu bylo zjistit, jaké skupiny studentů lze charakterizovat podle prediktorù úspěšnosti ve SPOC kurzu. Design výzkumu byl stanoven kvantitativnimi metodami sběru a vyhodnoceni dat. Dotazováni bylo provedeno pomoci vlastního dotazníku, kterého se účastnilo 44 respondentu. Získaná data byla analyzována pomocí vícerozměrných statistických dat, primárně metodami shlukové analýzy. Z výsledků výzkumu vyplynulo, že respondenty lze rozdělit podle 11 prediktorů úspěšnosti do dvou charakteristických skupin.

Klíčová slova: vzdělávání učitelů, e-learning, malé soukromé on-line kurzy, prediktory úspěšnosti

*Autor pro korespondenci: michal.mrazek@upol.cz 


\section{1 Úvod}

Vzdělávání v nejobecnějším pojetí prochází v posledních desetiletích výraznou transformací, která v mnoha směrech souvisí se začleňováním moderních technologií do vzdělávacího procesu. Významná oblast teorie a aplikace moderních technologií ve vzdělávání je reprezentována jako elektronické učení (e-learning). Jedná se o relativně nový pojem, který je znám od roku 1999 (Dvořáková et al., 2008), nicméně počátky e-learningu ve spojení s distančním vzděláváním nalezneme již v 60. letech minulého století (Stříteská, 2007). Ve vývoji elektronického učení se promítaly jednotlivé teorie učení, které vycházely z aktuálních přístupů ke vzdělávání v kontextu pedagogickopsychologických a didaktických aspektů implementace ICT technologií do procesu učení. Mezi tři nejvýznamnější teorie učení, které se promítaly do formování elektronického učení, řadíme behaviorismus, kognitivní psychologii a konstruktivismus (Klement, 2017).

Nynější podoba e-learningu nabývá různých forem s ohledem na využití především v souvislosti s distančním vzděláváním. Nejčastější zastoupení má e-learning v univerzitním vzdělávání, obecněji v terciárním sektoru vzdělávání a taktéž výrazně zasahuje do celoživotního vzdělávání (Klement, Dostál, 2018). Současný trend e-learningu směřuje $\mathrm{k}$ on-line vzdělávání, které $\mathrm{v}$ různých podobách nabralo v posledním desetiletí výrazně na oblibě a akcelerace jeho vývoje byla enormní. Především dostupnost informací v on-line prostředí je dnes možná téměř pro kohokoliv, odkudkoliv a kdykoliv, pouze $\mathrm{s}$ připojením $\mathrm{k}$ internetu. Tato skutečnost přináší lidem nepřeberné možnosti vzdělávat se a rozvíjet $\mathrm{v}$ různých oblastech poznání a činností, a to i nezávisle na vzdělávacích systémech a institucích. Zmíněné možnosti on-line vzdělávaní, společně s nově se rozvíjejícím pedagogickým konceptem moderního učení, který byl nazván konektivismus, položily základy masivních otevřených on-line kurzů (MOOC), kdy historie prvního kurzu této podoby sahá do roku 2008 a jehož autory byly G. Siemens a S. Downes. Autoři navrhli kurz v LMS Moodle, původně pro malou skupinu účastníků, nicméně poté se rozhodli kurz otevř́it veřejnosti a výsledkem bylo, že se přihlásilo přibližně 2200 účastníků (Porter, 2015). Od té doby vzniklo několik tisíc různých kurzů od různých poskytovatelů a zapojilo se do nich miliony účastníků (Emmons et al., 2017). Přestože se tento typ kurzu těší velkého zájmu, někteří autoři poukazují na značnou nevýhodu MOOC kurzů, a to především ve velmi nízkém počtu účastníků, kteří kurz dokončí. Úspěšnost účastníků při dokončení kurzů se pohybuje okolo 4-9 \%, výjimečně nad $10 \%$ (Porter, 2015; Rai, Chunrao, 2016). V roce 2013 profesor Fox na universitě Berkley navrhl první SPOC (malý soukromý on-line kurz). SPOC byl považován za smíšený vyučovací režim vyvinutý pro potřeby univerzitního prostředí jako paralelní typ kurzu k MOOC, přičemž charakterizovat SPOC je možné jako typ kurzu, který aplikuje učební zdroje, způsoby a metody MOOC do reálného prostředí tř́́d (Gou, 2017). Způsob a forma realizace SPOC se v současnosti mnohdy výrazně liší, nebot' mezi odborníky není ustálena jednotně platná definice. Můžeme se setkat se SPOC kurzy, které probíhají pouze v on-line podobě (Uijil, 2017). Při analýze současného trendu implementace malých soukromých on-line kurzů se definice více shodují s původním záměrem A. Foxe (2013) a v rámci pedagogických přistupů jsou SPOC spojovány s teoriemi hybridního vzdělávání - blended learning (Kaplan, Haenlein, 2016; Muñoz-Merino, 2017) nebo s teorií převrácených tříd (Delgado Kloos, 2014). Hlavní rozdíly mezi oběma typy kurzo̊ jsou především v počtu účastníků, kdy ve SPOC jsou obvykle desítky účastníků na rozdíl od MOOC, kde se počty účastníků pohybují v rámci stovek i tisíců. 
Ve SPOC kurzu instruktoři používají hybridní přístup $\mathrm{k}$ výuce, kombinující on-line nástroje $\mathrm{s}$ tradičními metodami výuky, kdy nastavení kurzu slouží omezenému počtu studentů. V mnoha SPOC kurzech instruktor nevytváŕí on-line obsah nový, ale na místo toho přizpůsobí obsah masivního otevřeného on-line kurzu (MOOC). Zde ale musí platit předpoklad, že již takový MOOC kurz existuje. Osobní setkání ve SPOC mají za cíl rozvíjet a prohlubovat porozumění obsahu studentům a on-line komponenta tento účel podporuje (Kurt, 2018).

Naše definice Small Private Online Course (SPOC) je dána následujícím způsobem:

Malý soukromý (uzavřený) on-line kurz je souborem vzdělávacích aktivit, které probíhají částečně či plně v režimu on-line, př́ípadně formou blended learningu, ovšem vždy ve stanoveném časovém rozmezí výuky, za podpory technologií a systémových aplikací, umožňujících řízení edukačního procesu, formou implementovaných nástrojů, prostředků a vzdělávacích materiálů, kterými je zprostředkovávána komunikace mezi aktéry kurzu, předávání výukového obsahu a hodnocení aktivit, přičemž počet aktérů je nízký, obvykle v řádu desítek, vybraných na základě stanovených kritérií a tvořících skupinu se stejným či obdobným vzdělávacím zaměřením (Průcha et al., 2008; Boettcher, 2009; Klement et al., 2012; Oremus, 2013; Coughlan, 2013; Kaplan, Haenlein, 2016; Zounek et al., 2016; Gou, 2017; Uijil, 2017; Kurt, 2018).

\section{Prediktory úspěchu ve SPOC}

Školní úspěch žáků či studentů je ovlivňován souborem činitelů, které označujeme jako prediktory úspěchu. Soubor těchto prediktorů, které jsou si podobné a mají společný vliv na školní úspěch, můžeme obecněji nazývat jako faktory úspěchu (Ivcevic, Brackett, 2014). Predikce školní úspěšnosti, stejně tak jako úspěšnosti ve SPOC kurzu, je náročnou úlohou s ne vždy zcela jednoznačnými výsledky, nebot' jsou multifaktorově podmíněny. Obecně přijímaná teorie školní úspěšnosti vymezuje významné faktory úspěchu, které je možné prezentovat jako faktory: charakteristika žáka, charakteristika učitele, charakteristika rodinného zázemí (charakteristika socio-ekonomického zázemí) aj., které se ovšem s typem, úrovní školy či formou vzdělávání budou částečně lišit (Mareš, 2013; Helus et al., 1979). V prostředí univerzitního vzdělávání je úspěšnost studentů vnímána především v kontextu splnění zkoušek nebo termínu dokončení studia (Perger, Takács, 2016). Kvalitativní př́stup $\mathrm{k}$ identifikaci podmínek úspěšnosti studentů $\mathrm{v}$ terciárním sektoru vzdělávání nabízí predikční model úspěšnosti. Faktory: akademický, demografický, institucionální, psychologický nebo ekonomický, jsou v tomto modelu reprezentovány dílčími podmínkami, prediktory úspěchu (Al-Sudani, Palaniappan, 2019). $\mathrm{V}$ př́ípadě elektronického učení formou on-line kurzu zde budou mít významnou roli další prediktory úspěchu, které můžeme prezentovat jako technologický faktor. Mezi technologické prediktory řadíme např́íklad typ a organizovanost on-line vzdělávacího prostředí, variabilitu učebních nástrojů a materiálů, dostupnost komunikačních nástrojů či technické zabezpečení kurzu (Volery, Lord, 2000; Ozkan, Koseler, 2009). Žák zaujímá $v$ rocesu edukace hlavní roli, jeho výsledky, respektive jeho úspěšnost závisí na predispozicích k učení, motivaci a podmínkách. Faktor charakteristik žáka (studenta) zahrnuje následující prediktory, které se podílejí na úspěšnosti v on-line kurzu: osobnost žáka, styl učení žáka, studijní motivace žáka, socio-ekonomické zázemí, předchozí zkušenost se vzdělávacím obsahem, předchozí zkušenost $\mathrm{s}$ on-line vzděláváním, absence zdravotních komplikací (Mareš, 2013; Cyrilleet al., 2011; Urval et al., 2014; Kerr et al., 2006). 


\section{Metodologie}

Výzkumné šetření vycházelo z analýzy odborné literatury (viz kap. 2) orientované na problematiku: školní úspěšnosti žáků a studentů, predikci úspěšnosti, faktorů a prediktorů úspěšnosti v e-learningu a on-line kurzech. Výzkumný problém byl konkretizován v rámci teoretické oblasti se zaměřením na diverzifikaci studentů podle prediktorů úspěšnosti studentů ve SPOC. Vybrané prediktory úspěšnosti byly vymezeny v souvislosti s dílčími oblastmi úspěchu v rámci faktoru charakteristika studenta (žáka).

Cíl výzkumu: Zjistit, jaké skupiny studentů lze charakterizovat podle jejich názorů na významnost prediktorů úspěšnosti ve SPOC kurzu v souvislosti $\mathrm{s}$ charakteristikou studenta. $Z$ tohoto cíle vyplývají následující výzkumné předpoklady.

\section{Výzkumné předpoklady:}

Výzkumný předpoklad $\mathbf{P}_{1}$ - Mezi studenty se vyskytuje 2 a více rozdílných skupin podle prediktorů úspěchu ve SPOC kurzu.

Výzkumný předpoklad $\mathbf{P}_{2}$ - Rozdíly mezi skupinami jsou dány alespoň $60 \%$ analyzovaných prediktorů úspěšnosti.

Výzkumný předpoklad $\mathbf{P}_{\mathbf{3}}-\mathrm{Na}$ rozdílech mezi skupinami studentů se nejvíce podílejí prediktory z oblasti znalostí a dovedností s ICT.

Design výzkumu byl zvolen v podobě kvantitativního výzkumného šetření. Pro sběr dat byl použit vlastní dotazník, který obsahoval celkem 43 položek, které zjišt'ovaly subjektivní názory studentů na prediktory, které jsou podle nich významné pro úspěšnost v kurzu Jedna otázka zjišt’ovala demografickou informaci (věk). Následující položky odpovídaly jednotlivým stanoveným prediktorům úspěšnosti, které byly rozděleny do dílčích oblastí predikce úspěšnosti v rámci faktoru charakteristika studenta (viz tab. č. 1). Dotazník obsahoval škálové položky, položky s možností jednoho výběru a dichotomickou položku na zjištění demografického údaje. Respondenti u škálových otázek volili na stupnici (1. úplný nesouhlas - 7. úplný souhlas) míru jejich subjektivního souhlasu $\mathrm{s}$ danými prediktory. Distribuce dotazníků studentům proběhla elektronicky. Při tvorbě vlastního dotazníku byly respektovány zásady tvorby výzkumných dotazníků (Brace, 2018).

\begin{tabular}{|c|c|}
\hline Č́slo otázky & Oblast položek podle charakteru zjišt’ovaných prediktorů \\
\hline $1-6$ & Motivace ke studiu na VŠ \\
\hline $7-13$ & Motivace ke studiu vzdělávacího oboru \\
\hline $14-16$ & Motivace ke studiu daného předmětu \\
\hline $17-21$ & Motivace ke studiu danou vzdělávací formou (SPOC) \\
\hline 22 & Dosavadní zkušenosti s e-learningem (se SPOC) \\
\hline 23 & Dosavadní zkušenosti se vzdělávacím obsahem \\
\hline $24-34$ & Znalosti a dovednosti s vybranými nástroji ICT \\
\hline $35-40$ & Rodinné zázemí (sociální podmínky) \\
\hline $41-42$ & Zdravotní stav \\
\hline
\end{tabular}

Tab. č. 1: Oblasti a četnosti položek podle charakteru zjištovaných prediktorů. 
Respondenti byli studenti bakalářského studia oboru Základy technických věd a informačních technologií pro vzdělávání na Univerzitě Palackého v Olomouci. Celkem byly vyhodnoceny dotazníky od 40 respondenti̊. Jednalo se o studenty, kteří absolvovali alespoň jeden ze SPOC kurzů Základy programováni nebo Informační technologie a informatika. Ověření reliability dotazníkového nástroje bylo provedeno pomocí Cronbachova $\alpha$. Reliabilita vykazovala hodnotu 0,662 což znamená, že dotazník můžeme považovat za spolehlivý měrný nástroj. Nicméně u dvou položek (č. 34 a 39) dotazníku bylo zjišsěno, že jednoznačně snižují spolehlivost dotazníku. $V$ př́ípadě položky č. 34 je možné, že byla studenty vnímána jako duplicitní k položce č. 2. (č. 2 - očekávání rodiny studia na VŠ; č. 34 - podpora rodiny při studiu na VŠ). Po jejich odstranění vykazovala hodnota Cronbachova $\alpha$ hodnotu 0,706. Návratnost všech dotazníků činila $90 \%$. U čtyřech respondentů nebylo možné data zahrnout do analýzy z důvodů, že dotazníky nebyly kompletně vyplněny. Rozdělení výzkumného vzorku podle pohlaví je uvedeno v grafu č. 1 , včetně prípadů s nekompletními daty.



Graf č. 1: Struktura výzkumného vzorku.

Veškeré statistické analýzy byly provedeny statistickým softwarem Statistica 12. Pro vyhodnocení získaných dat $\mathrm{v}$ rámci ověřování výzkumných předpokladů byly využity vícerozměrné statistické metody. Shlukovou analýzu řadíme mezi vícerozměrné statistické metody, které se použivají ke klasifikaci objektů. Pomocí těchto metod jsou jednotky trríděny do skupin (shlukủ) tak, aby si jednotky náležící do stejné skupiny byly podobnější než objekty z ostatních skupin (Vellido et al., 2011). Vytvoření orientačního modelu možných skupin studentů bylo provedeno pomocí hierarchické shlukové analýzy. Ověření orientačního modelu bylo realizováno globalizovanou shlukovou analýzou K-means a aplikací analýzy rozptylu ANOVA. 


\section{Výsledky}

Orientační model možných skupin studentů byl zjišt'ován pomocí shlukové analýzy s hierarchickým pravidlem shlukování úplného spojení podle euklidovské vzdálenosti. Na základě této metody bylo možné vytvořit grafické znázornění rozdělení studentů podle vzájemně podobných znaků (proměnných v podobě prediktorů úspěchu). Orientační model č. 1 je znázorněn $v$ grafu č. 2 .

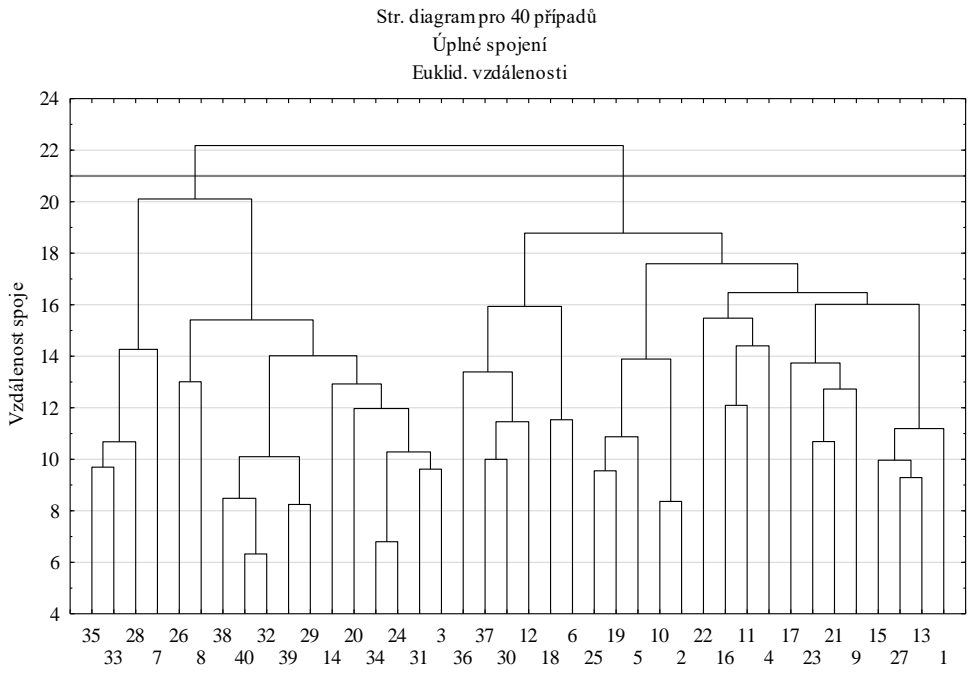

Graf č. 2: Dendrogram shlukování (úplné spojení) - Model skupin č. 1.

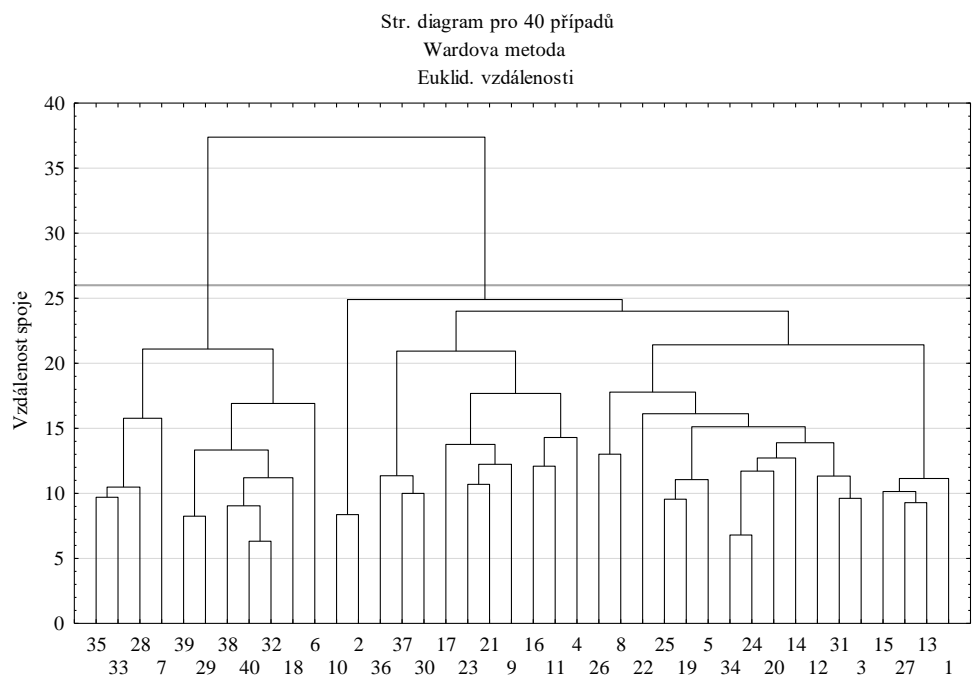

Graf č. 2: Dendrogram shlukování (Wardova metoda) - Model skupin č. 2. 
Následně byla provedena další shluková analýza s odlišným hierarchickým pravidlem shlukování Wardovy metody podle euklidovské vzdálenosti. Orientační model č. 2 je znázorněn v grafu č. 3 . Do obou analýz položek byla zahrnuta další proměnná v podobě znaku hodnocení úspěšnosti studentů.

Oba orientační modely bylo možné porovnat a $\mathrm{z}$ toho určit, zda použití shlukové analýzy s rozdílnými pravidly shlukování nepřinese zcela odlišné výsledky. Míra shody mezi oběma modely je dána $72,5 \%$ zastoupením respondentů $\mathrm{v}$ témže klastru $\mathrm{v}$ rámci obou modelů, přičemž oba modely dochází $\mathrm{k}$ výsledkům rozdělení studentů do dvou patrných skupin. $\mathrm{Z}$ toho můžeme usuzovat, že použití shlukové analýzy je relevantní. V nejvyšší možné hladině vzdálenosti spojení (graf č. 2 - hodnota 21; graf č. 3 - hodnota 26), tedy $\mathrm{v}$ obecné rovině můžeme studenty rozdělit do dvou jednoznačných skupin. Vymezení specifických rozdílů mezi oběma skupinami v obecné rovině není pomocí této statistické metody možné.

V př́padě vyššího počtu respondentů by bylo možné usuzovat vývoj orientačních modelů. Posunutím hladiny vzdálenosti spojení na aktuálních grafech (graf č. 2 - hodnota 28; graf č. 3 - hodnota 23) lze identifikovat možné další dělení studentů do dílčích podskupin. K jejich relevantní charakteristice by bylo ovšem nutné počet studentů zvýšit.

Pro analýzu proměnných $\mathrm{v}$ podobě dotazníkových položek prediktorů úspěchu byla využita generalizovaná shluková analýza nehierarchického typu s tř́́dícím algoritmem K-means (tab. č. 2), která určila jednoznačný počet shluků dle významných rozdílů $\mathrm{v}$ odpovědích respondentů. Významné rozdíly byly určeny pomocí signifikantních hodnot, které byly určeny aplikací analýzy rozptylu ANOVA.

\begin{tabular}{|c|c|}
\hline \multicolumn{2}{|c|}{$\begin{array}{l}\text { Výsledek pro K-means shlukování (DATA_SPOC_analyza) } \\
\text { Počet klastrů: } 2 \\
\text { Celkový počet testovaných př́padů: } 40\end{array}$} \\
\hline Algoritmus & K-means \\
\hline Metoda vzdálenosti spojení & Euklidovská vzdálenost \\
\hline Počáteční vzdálenost & Úplné spojení \\
\hline Smazání CHD př́ípadů & Ano \\
\hline Kř̌ižové ověření & 10krát \\
\hline Testované vzorky & 0 \\
\hline Testované př́ípady & 40 \\
\hline Testová chyba & 1,809372 \\
\hline Počet klastrů & 2 \\
\hline
\end{tabular}

Tab. č. 2: Výsledek K-means shlukování.

Na základě této analýzy se potvrdilo, že lze studenty rozdělit do dvou jednoznačných skupin. Zároveň bylo ovšem zjištěno podrobnou analýzou rozdělení respondentů, že konkrétní rozdělení jednotlivců se jen částečně shoduje s orientačními modely. Výsledky K-means shlukování jsou uvedeny v tab. č. 3 . 


\begin{tabular}{|c|c|c|c|c|c|}
\hline $\begin{array}{l}\text { Shlukov } \\
\text { Počet kl } \\
\text { Celkový }\end{array}$ & $\begin{array}{l}\text { aní respond } \\
\text { strů: } 2 \\
\text { počet testov }\end{array}$ & $\begin{array}{l}\text { ntů (DATA } \\
\text { ných př́pac }\end{array}$ & $\begin{array}{l}\text { SPOC_ } \\
\text { u: } 40 \\
\end{array}$ & alyza & \\
\hline $\begin{array}{l}\text { Název } \\
\text { případu }\end{array}$ & $\begin{array}{c}\text { Konečná } \\
\text { klasifikace } \\
\text { (klastr) }\end{array}$ & $\begin{array}{l}\text { Vzdálenost } \\
\text { od těžiště }\end{array}$ & \begin{tabular}{|} 
Název \\
př́ípadu
\end{tabular} & $\begin{array}{c}\text { Konečná } \\
\text { klasifikace } \\
\text { (klastr) }\end{array}$ & $\begin{array}{l}\text { Vzdálenost } \\
\text { od těžiště }\end{array}$ \\
\hline 1 & 1 & 2,084284 & 21 & 2 & 1,596495 \\
\hline 2 & 2 & 1,967050 & 22 & 2 & 1,882164 \\
\hline 3 & 1 & 1,405529 & 23 & 2 & 1,476034 \\
\hline 4 & 2 & 1,909619 & 24 & 2 & 1,157608 \\
\hline 5 & 2 & 1,926995 & 25 & 1 & 1,173892 \\
\hline 6 & 2 & 2,033470 & 26 & 2 & 1,834941 \\
\hline 7 & 2 & 2,503415 & 27 & 1 & 1,401989 \\
\hline 8 & 1 & 1,952661 & 28 & 2 & 1,877360 \\
\hline 9 & 2 & 1,815063 & 29 & 1 & 2,262799 \\
\hline 10 & 2 & 2,355545 & 30 & 2 & 2,056061 \\
\hline 11 & 1 & 1,738797 & 31 & 1 & 1,606799 \\
\hline 12 & 2 & 1,518716 & 32 & 2 & 1,966074 \\
\hline 13 & 1 & 1,514208 & 33 & 2 & 2,015544 \\
\hline 14 & 1 & 1,910045 & 34 & 2 & 1,418510 \\
\hline 15 & 1 & 1,513317 & 35 & 2 & 2,156237 \\
\hline 16 & 2 & 1,963178 & 36 & 2 & 2,258992 \\
\hline 17 & 1 & 2,037714 & 37 & 2 & 1,862568 \\
\hline 18 & 2 & 1,575941 & 38 & 1 & 2,125833 \\
\hline 19 & 1 & 1,342323 & 39 & 1 & 2,127159 \\
\hline 20 & 1 & 1,498912 & 40 & 2 & 1,551030 \\
\hline
\end{tabular}

Tab. č. 3: Výsledné zar̆azení respondentů do klastrů.

Komparací výsledků generalizované shlukové analýzy K-means a jednotlivých modelů zjištěných hierarchickými metodami shlukování bylo zjištěno, že shoda začlenění respondentů do totožných skupin není jednoznačná. $V$ př́padě srovnání $K$-means a modelu č. 1 je celková shoda začlenění respondentů do stejných shluků $55 \%$. V př́ípadě srovnání K-means s modelem č. 2 je celková shoda začlenění respondentů $60 \%$. Na základě těchto zjištění lze usuzovat, že zjištěné modely jsou opravdu jen orientační a za relevantní výsledek lze považovat zjišstění pomocí generalizované shlukové analýzy K-means. Tato metoda jednoznačné určila 2 skupiny respondentů, kdy menší skupina je tvořena $35 \%$ respondentů a větší skupina $65 \%$ respondentů. Konkrétní prediktory úspěšnosti, které odlišující obě skupiny, jsou uveden $\mathrm{v}$ tab. č. 4 . Zde jsou znázorněny pouze ty prediktory, které dosáhly signifikance $p<0,05$, tedy statisticky významného rozdílu. 


\begin{tabular}{|c|c|c|c|c|c|c|}
\hline \multirow[b]{2}{*}{ Položka } & \multicolumn{6}{|c|}{$\begin{array}{l}\text { ANOVA pro spojité proměnné } \\
\text { (DATA_SPOC_analyza } \\
\text { Počet klastrů: } 2 \\
\text { Celkový počet testovaných př́ípadů: } 40\end{array}$} \\
\hline & Mezi SČ & sv & Bez SČ & sv & $\mathrm{F}$ & $\begin{array}{c}\mathrm{p} \\
\text { hodnota }\end{array}$ \\
\hline $\begin{array}{l}\text { 1. Prodloužení doby před } \\
\text { nástupem do práce. }\end{array}$ & 24,38438 & 1 & 103,8906 & 38 & 8,91906 & 0,004919 \\
\hline $\begin{array}{l}\text { 10. Menší finanční } \\
\text { náročnost studia v rámci } \\
\text { oboru. }\end{array}$ & 17,87604 & 1 & 108,7240 & 38 & 6,24784 & 0,016871 \\
\hline $\begin{array}{l}\text { 11. Náročnost studia } \mathrm{v} \\
\text { rámci oboru. }\end{array}$ & 17,87604 & 1 & 111,0677 & 38 & 6,11600 & 0,017983 \\
\hline $\begin{array}{l}\text { 13. Možnosti studentského } \\
\text { života v rámci studovaného } \\
\text { oboru. }\end{array}$ & 49,05104 & 1 & 104,6927 & 38 & 17,80391 & 0,000146 \\
\hline $\begin{array}{l}\text { 17. Alternativní způsob } \\
\text { vzdělávání (Mohu si } \\
\text { vyzkoušet jiný způsob } \\
\text { vzdělávání). }\end{array}$ & 33,37604 & 1 & 156,5677 & 38 & 8,10058 & 0,007095 \\
\hline $\begin{array}{l}\text { 18. Flexibilita způsobu } \\
\text { vzdélávání }\end{array}$ & 27,67604 & 1 & 152,3177 & 38 & 6,90458 & 0,012332 \\
\hline $\begin{array}{l}\text { 21. Rád pracuji s } \\
\text { digitálními technologiemi }\end{array}$ & 11,92604 & 1 & 50,8177 & 38 & 8,91795 & 0,004921 \\
\hline $\begin{array}{l}\text { 26. Jaké máte znalosti } \\
\text { a dovednosti s } \\
\text { prezentačními } \\
\text { editory/procesory? }\end{array}$ & 11,05104 & 1 & 44,8490 & 38 & 9,36342 & 0,004047 \\
\hline $\begin{array}{l}\text { 27. Jaké máte znalosti } \\
\text { a dovednosti s programy na } \\
\text { úpravu zvukových } \\
\text { záznamů? }\end{array}$ & 18,42604 & 1 & 67,5677 & 38 & 10,36278 & 0,002633 \\
\hline $\begin{array}{l}\text { 34. Jaké máte znalosti } \\
\text { a dovednosti } \\
\text { s programátorskými } \\
\text { a vývojáŕskými programy? }\end{array}$ & 14,50417 & 1 & 101,8958 & 38 & 5,40904 & 0,025469 \\
\hline $\begin{array}{l}\text { 38. Podporují vás prrátelé } \\
\text { při studiu na VŠ? }\end{array}$ & 17,06667 & 1 & 68,4271 & 38 & 9,47773 & 0,003850 \\
\hline
\end{tabular}

Tab. č. 4: Výsledky analýzy ANOVA - signifikantni rozdily mezi skupinami.

Statisticky významné rozdíly byly identifikovány u 11 položek prediktorů úspěchu, což činí $26 \%$ ze všech analyzovaných položek. 
Výzkumný předpoklad $\mathbf{P}_{\mathbf{1}}$ - mezi studenty se vyskytuje 2 a více rozdílných skupin podle prediktorů úspěchu ve SPOC kurzu, byl potvrzen.

Orientační modely možných skupin studentů zjištěné pomocí shlukové analýzy s hierarchickým pravidlem shlukování (Úplného spojení a Wardovou metodou) podle euklidovské vzdálenosti a hledání signifikantních skupin studentů s použitím generalizované shlukové analýzy nehierarchického typu s tř́dícím algoritmem K-means a aplikací analýzy ANOVA ukázaly, že ve zkoumaném vzorku jsou dvě jednoznačně identifikovatelné skupiny.

Výzkumný předpoklad $\mathbf{P}_{2}$ - rozdíly mezi skupinami jsou dány alespoň $60 \%$ analyzovaných prediktorů, nebyl potvrzen.

Rozdíly mezi identifikovanými skupinami studentů jsou vymezeny pouze $26,5 \%$ analyzovaných prediktorů.

\section{Charakteristika zjištěných skupin studentů}

Popisná charakteristika zjištěných skupin studentů byla podložena analýzou významných položek, které určily rozdíl mezi oběma skupinami. Nejprve bylo ověřeno, které charakteristické oblasti prediktorů zahrnují významné položky. Tím došlo k redukci 11 položek prediktorů do 5 specifických oblastí (tab. č. 5), podle původního rozdělení (tab. č. 1). Pro každou oblast byla vypočtena průměrná hodnota odpovědí na jednotlivé položky prediktorů. Zároveň byly do analýzy zahrnuty výsledné známky studentů ve SPOC. Výsledné známky byly zprůměrovány podle skupin (tab. č. 5).

\begin{tabular}{|c|c|c|c|c|}
\hline $\begin{array}{l}\text { Č́́slo } \\
\text { otázky }\end{array}$ & $\begin{array}{c}\text { Oblast položek podle } \\
\text { charakteru zjišs'ovaných } \\
\text { prediktorù }\end{array}$ & $\begin{array}{c}\text { Počet } \\
\text { signifikantních } \\
\text { prediktorů }\end{array}$ & $\begin{array}{c}\text { Ø hodnota } \\
\text { odpovědí } \\
\text { Klastr } 1\end{array}$ & $\begin{array}{c}\text { Ø hodnota } \\
\text { odpovědí } \\
\text { Klastr } 2\end{array}$ \\
\hline $1-6$ & Motivace ke studiu na VŠ & 1 & 1,719 & 3,313 \\
\hline $7-13$ & $\begin{array}{l}\text { Motivace ke studiu } \\
\text { vzdělávacího oboru }\end{array}$ & 3 & 3,500 & 4,264 \\
\hline $14-16$ & $\begin{array}{c}\text { Motivace ke studiu daného } \\
\text { předmětu }\end{array}$ & 0 & - & - \\
\hline $17-21$ & $\begin{array}{l}\text { Motivace ke studiu danou } \\
\text { vzdělávací formou (SPOC) }\end{array}$ & 3 & 3,594 & 5,153 \\
\hline 22 & $\begin{array}{l}\text { Dosavadní zkušenosti s e- } \\
\text { learningem (se SPOC) }\end{array}$ & 0 & - & - \\
\hline 23 & $\begin{array}{l}\text { Dosavadní zkušenosti se } \\
\text { vzdělávacím obsahem }\end{array}$ & 0 & - & - \\
\hline 24-34 & $\begin{array}{c}\text { Znalosti a dovednosti } \\
\text { s vybranými nástroji ICT }\end{array}$ & 3 & 4,354 & 4,868 \\
\hline $35-40$ & $\begin{array}{l}\text { Rodinné zázemí (sociální } \\
\text { podmínky) }\end{array}$ & 1 & 6,438 & 5,104 \\
\hline $41-42$ & Zdravotní stav & 0 & - & - \\
\hline & \multicolumn{2}{|c|}{$\varnothing$ hodnocení studentů v kurzu } & 2,32 & 2,22 \\
\hline
\end{tabular}

Tab. č. 5: Zařazení položek dotazníku do specifických oblastí 
Rozdíl mezi skupinami $\mathrm{v}$ dosaženém hodnocení studentů ve SPOC byl ověřován pomocí parametrického statistického testu T-test pro nezávislé skupiny. Hladina významnosti $\alpha=0,05$ byla porovnána s výslednou signifikancí T-testu $\mathrm{p}=0,6843$. Věcná hypotéza o rozdílech mezi skupinami v dosaženém skoré nebyla potvrzena. Výsledkem je, že mezi skupinami není statisticky významný rozdíl v dosaženém hodnocení. Vzhledem k tomu, že nebyl dodržen požadavek homogenity rozptylů (F-test), byl výsledek T-testu ještě ověřen pomocí neparametrického testu Mann-Whitney U test, který je možné použít jako alternativu k parametrickému T-testu (Chráska, 2016). I v tomto př́padě nebyly rozdíly potvrzeny, nebot' signifikance $\mathrm{p}=0,6926$ dosáhla vyšší hodnoty než hladina významnosti $\alpha=0,05$ a nulovou hypotézu tedy nebylo možné zamítnout.

V př́padě tohoto vzorku respondentů nelze výsledné rozdíly mezi identifikovanými skupinami na základě prediktorů úspěchu interpretovat v souvislosti s dosažením lepších výsledků ve SPOC. Obě skupiny studentů dosáhly téměř totožných výsledků a jejich deskripce je možná pouze v kontextu rozdílných charakteristik, které byly zjištěny.

Skupina 1 nepovažuje při absolvování SPOC kurzu za důležitou motivovanost ke studiu na vysoké škole (univerzitě). Motivace ke studiu vzdělávacího oboru, motivace ke studiu danou vzdělávací formou (SPOC) a znalosti a dovednosti s vybranými nástroji ICT, jsou oblasti, které se významně podílejí na odlišení obou skupin. Skupina 1 tyto oblasti vnímá neutrálně v kontextu důležitosti při absolvování SPOC kurzu. Velmi zajímavý pohled přináši výsledek oblasti Rodinného zázemí (sociální podmínky), především prediktor podpora přátel při studiu VŠ. Skupina 1 tuto charakteristiku vnímá jako velmi důležitou. Zde bychom mohli předpokládat, že studenti v rámci absolvování SPOC kurzu kooperují a své spolužáky v tomto prŕípadě řadí mezi přátele, kteří je podporují.

Skupina 2 vnímá motivovanost ke studiu na vysoké škole (univerzitě) při absolvování SPOC kurzu neutrálně, stejně tak i motivace ke studiu vzdělávacího oboru. Ostatní významné oblasti vnímají již jako důležité, nicméně vnímání podpory přátel při studiu VŠ není tolik důležité, jako u skupiny 1 .

Předpoklad $\mathbf{P}_{\mathbf{3}}$ - na rozdílech mezi skupinami studentů se nejvíce podílejí prediktory z oblasti znalostí a dovedností s ICT, nebyl potvrzen.

Oblast znalostí a dovedností s ICT je sice mezi významnými oblastmi, které charakterizují rozdíly mezi skupinami studentů, ale nepodílejí se na těchto rozdílech nejvíce.

\section{Závěr}

Naše výzkumná zjištění ukázala, že je možné studenty ve SPOC kurzu dělit na dvě skupiny podle prediktorů úspěšnosti. Menší skupinu tvořilo $35 \%$ respondentů a větší skupina byla zastoupena $65 \%$ respondentů. Náš výzkumný předpoklad byl potvrzen na základě modelů možných skupin studentů zjištěných pomocí shlukové analýzy s hierarchickým pravidlem shlukování (Úplného spojení a Wardovou metodou) podle euklidovské vzdálenosti. Signifikantnost existence dvou skupin bylo možné potvrdit použitím generalizované shlukové analýzy nehierarchického typu s trrídícím algoritmem K-means a aplikací analýzy ANOVA. Pomocí těchto statistických metod bylo zjištěno, že rozdělení studentů do skupin určuje pouze $26 \%$ prediktorů z celkového počtu. Druhý výzkumný předpoklad tímto nebyl potvrzen. Otevírá se proto prostor k diskuzi, zda tak nízký počet prediktorů může věcně charakterizovat významné rozdíly mezi skupinami studentů ve SPOC kurzech, př́padně zda se nejedná pouze o jedinečnost v rámci zkoumaného vzorku. 
Srovnávací analýzou výsledků generalizované shlukové analýzy K-means s jednotlivými modely zjištěnými hierarchickými metodami shlukování bylo zjištěno, že shoda začlenění respondentů do totožných skupin není jednoznačná. $V$ príípadě srovnání K-means a modelu č. 1 je celková shoda začlení respondentů do stejných shluků $55 \%$. $\mathrm{V}$ př́ípadě srovnání K-means $\mathrm{s}$ modelem č. 2 je celková shoda začlení respondentů $60 \%$. Z tohoto závěru lze usuzovat, že zjištěné modely shluků jsou opravdu jen orientační a za relevantní výsledek lze považovat zjištění pomocí generalizované shlukové analýzy K-means.

Jako podstatný bod výzkumu se ukázala realizace testů významnosti rozdílů mezi skupinami $\mathrm{v}$ jejich dosaženém hodnocení $\mathrm{v}$ kurzu. Rozdíly $\mathrm{v}$ hodnocení nebyly signifikantně prokázány. Proto není možné u tohoto vzorku respondentů výsledné rozdíly mezi identifikovanými skupinami na základě prediktorů úspěchu interpretovat v souvislosti s dosažením lepších výsledků ve SPOC kurzu. Obě skupiny studentů dosáhly téměř totožných výsledků a jejich deskripce byla možná pouze v kontextu rozdílných charakteristik, které byly zjištěny.

Po zařazení jednotlivých prediktorů do dílčích oblastí predikce úspěšnosti v rámci faktoru charakteristika studenta bylo zjiššeno, že na rozdělení studentů do skupin se podílí 5 následujících oblastí: Motivace ke studiu na VŠ; Motivace ke studiu vzdělávacího oboru; Motivace ke studiu danou vzdělávací formou (SPOC); Znalosti a dovednosti s vybranými nástroji ICT; Rodinné zázemí (sociální podmínky). Zajímavým výsledkem pro nás byla identifikace oblasti Rodinného zázemí (sociální podmínky), především prediktor podpora př́tel při studiu VŠ. Identifikovaná skupina 1 tuto charakteristiku vnímá jako velmi důležitou. Zde bychom mohli předpokládat, že studenti v rámci absolvování SPOC kurzu kooperují a své spolužáky $\mathrm{v}$ tomto př́padě řadí mezi přátele, kteří je podporují.

Zároveň se nám nepodařilo ověřit výzkumný předpoklad $\mathrm{P}_{3}$, nebot' oblast znalostí a dovedností s ICT je sice mezi významnými oblastmi, které charakterizují rozdíly mezi skupinami studentů, ale nepodílejí se na těchto rozdílech největši měrou.

V rámci realizovaného výzkumu vidíme určité limity našich zjištění. Hlavní limit shledáváme $\mathrm{v}$ malém rozsahu zkoumaného vzorku respondentů, který je ovšem dán počtem přihlášených studentů do kurzů a obecně typologií malých soukromých on-line kurzů (SPOC). Předpokládáme, že zkoumání dat většího vzorku respondentů by rozkrylo další možnosti dělení studentů podle prediktorů úspěšnosti. Tuto skutečnost naznačují i orientační modely rozdělení studentů (graf č. 2; graf č. 3). Dále př̌edpokládáme, že rozšiření vzorku by vedlo ke zvyšující se tendenci počtu významných prediktorů, které by měly vliv na rozdělení studentů do skupin a taktéž by se projevily větší rozdíly v hodnocení (úspěšnosti) studentů.

$\mathrm{Na}$ základě našich zjištění a výzkumných limitů si nedovolujeme jednoznačně výsledky zobecňovat pro všechny SPOC $\mathrm{s}$ různým zaměřením. Výsledky jsou charakteristické pro konkrétní skupinu studentů s konkrétním vzdělávacím zaměřením v rámci Univerzity Palackého v Olomouci.

Příspěvek vznikl za podpory projektu IGA_PdF_2019_043 s názvem Analýza vybraných aktuálních problémů ve výuce informaticky zaměřených předmětů s akcentem na on-line technologie 


\section{Literatura}

Al-Sudani, S. \& Palaniappan, R. (2019). Predicting students' final degree classification using an extended profile. Education and Information Technologies. 24. 2357-2369. DOI: 10.1007/s10639-019-09873-8

Boettcher, J. V. (2009). Designing online learning programs. In Rogers, P. I., Berg, G. A., Boettcher, J. V. \& kol. Encyclopedia of distance learning, 2 vyd. Hershey, PA: Information Science Reference. DOI: 10.4018/978-1-60566-198-8.ch085

Brace, I. (2018). Questionnaire Design: How to Plan, Structure and Write Survey Material for Effective Market Research, London: Kogan Page.

Coughlan, S. (24. záŕí 2013). Harvard plans to boldly go with 'Spocs'. [vid. 7. Leden 2019]. BBC Business News. Dostupné z: https://www.bbc.com/news/business-24166247

Cyrille, A. C. (2011). Looking for students' personal characteristics predicting study outcome. High Education. 61. 59-75. DOI: 10.1007/s10734-010-9325-7

Delgado Kloos, C., Muňoz-Merino, P.J., Muňoz -Organero, M., Alario-Hoyos, C., PérezSanagustín, M. Parada H.A., Ruiperez, J.A. \& Sanz, J.L. (2014). Experiences of Running MOOCs and SPOCs at UC3M. Proc. IEEE Global Engineering Education Conference (EDUCON). DOI:10.1109/EDUCON.2014.6826201

Dvořáková, M., Klisz, M., Neumeister, P., Opletalová, A., Stupková, V. \& Techlová, P. (2008). Problematika finančních a jiných zdrojů nejen v sociální sfére. Olomouc: HANEX, $86 \mathrm{~s}$.

Emmons, S. R., Light, R. P. \& Borner, K. (2017). MOOC Visual Analytics: Empowering Students, Teachers, Researchers, and Platform Developers of Massively Open Online Courses. Journal of the Association for Information Science and Technology. 68(10), 2350-2363. DOI: 10.1002/asi.23852

Guo, P. (2017). MOOC and SPOC, Which One is Better? EURASIA Journal of Mathematics Science and Technology Education. 13(8), 5961-5967. DOI: 10.12973/eurasia.2017.01044a

Helus, Z., Hrabal, V., Kulič, V. \& Mareš, J. (1979). Psychologie školní úspěšnosti žáka. Praha: SPN

Chráska, M. (2016). Metody pedagogického výzkumu: základy kvantitativního výzkumu, Praha: Grada Publishing.

Kaplan, A.M. \& Haenlein, M. (2016). Higher education and the digital revolution: About MOOCs, SPOCs, social media, and the Cookie Monster. Business Horizons. 59(4), 441 450. DOI 10.1016/j.bushor.2016.03.008

Kerr, M. S., Rynearson, K. \& Kerr, M. C. (2006). Student characteristics for online learning success. Internet and Higher Education. 6. 91-105. DOI: 10.1016/j.iheduc.2006.03.002

Klement, M. (2017). Teorie, styly a strategie učení(se) v e-learningu. Journal of Technology and Information Education. 9(1). 30-42. DOI: 10.5507/jtie.2016.014

Klement, M. \& Dostál, J. (2018). Teorie, východiska, principy a roz.voj distančního vzdélávání realizovaného formou e-learningu. Olomouc: Univerzita Palackého v Olomouci.

Klement, M., Chráska, M., Dostál, J. \& Marešová, H. (2012). E-LEARNING: elektronické studijni opory a jejich hodnoceni. Olomouc: GEVAK. 
Kurt, S. (18. května 2018). Fully and Partially Online Courses: Definitions. [vid. 15. ledna 2019] Educational Technology. Dostupné z: https://educationaltechnology.net/fully-andpartially-online-courses-definitions/ Mareš, J. (2013). Pedagogická psychologie. Praha: Portál.

Muňoz-Merino, P. J., Méndez Rodríguez, E., Kloos, C. D. \& Ruipérez-Valiente, J. A. (2017). Design, Implementation and Evaluation of SPOCs at the Universidad Carlos III de Madrid. Journal of Universal Computer Science. 23(2), 167-186.

Oremus, W. (18. záŕí 2013). Forget MOOCs. Slate - Innovation, the Internet, Gadgets, and more. [vid. 8. dubna 2019]. Dostupné z: https://slate.com/technology/2013/09/spocssmall-private-online-classes-may-be-better-than-moocs.html

Ozkan, S. \& Koseler, R. (2009). Multi-dimensional evaluation of E-learning systems in the higher education context: An empirical investigation of a computer literacy course. In Proceedings - Frontiers in Education Conference. San Antonio: IEEE. DOI: 10.1109/FIE.2009.5350590

Perger, M. \& Takács, I. (2016). Factors Contributing to Students’ Academic Success Based on the Students' Opinion at BME Faculty of Economic and Social Sciences. Periodica Polytechnica Social and Management Sciences. 24(2). 119-135. DOI: 10.3311/PPso.8843 Porter, S. (2015). To MOOC or Not to MOOC: How can online learning help to build the future of higher education? Waltham, MA: Chandos publishing.

Průcha, J., Walterová, E. \& Mareš, J. (2008). Pedagogický slovník. 4.vyd. Praha: Portál.

Rai, L., Chunrao, D. (2016). Influencing Factors of Success and Failure in MOOC and General Analysis of Learner Behavior. International Journal of Information and Education Technology. 6(4), DOI: 10.7763/IJIET.2016.V6.697

Stř́teská, H. (10. ledna 2007). Historie e-learningu v České republice. [vid. 3. ledna 2011]. Dostupné z: http://www.fi.muni.cz/usr/jkucera/pv109/2003p/xstrites.htm.

Uijil, S., Filius, R. \& Cate, O. T. (2017). Student Interaction in Small Private Online Courses. Medical Science Educator. 27(2), 237-242. DOI: 10.1007/s40670-017-0380-x

Urval, R. P. \& kol. (2014). Assessment of learning styles of undergraduate medical students using the VARK questionnaire and the influence of sex and academic performance. Adv Physiol Educ. 38. 216-220. DOI: 10.1152/advan.00024.2014

Vellido, A., Castro, F. \& Nebot, Á. (2011). Clustering educational data. In Romero, C. $\&$ kol. Handbook of Educational data mining. Boca Raton: CRC Press.

Volery, T. \& Lord, D. (2000). Critical success factors in online education. The international Journal of Educational Management. 14(5), 216-223.

Zounek, J. a kol. (2016). E-learning: učení (se) s digitálními technologiemi. Praha: Wolters Kluwer. 